\title{
Product-requirement-model to approach the identification of uncertainties in battery systems development
}

\author{
Heiner Hans Heimes ${ }^{1} \cdot$ Achim Kampker $^{1} \cdot$ Andreas Haunreiter $^{1}\left[\mathbb{D} \cdot\right.$ Henning Davids $^{1} \cdot$ Domenic Klohs $^{1}$
}

Received: 15 March 2020 / Accepted: 23 July 2020 / Published online: 7 August 2020

(c) The Author(s) 2020

\begin{abstract}
Electric mobility is on the verge of becoming a mass market. Major automotive OEMs have initiated programs to electrify their product portfolio. This transition poses new challenges and requires new innovative concepts in automotive development processes, especially for battery systems as the key component within electric powertrains. Battery system costs account for up to $40 \%$ of the electric vehicle's total costs. Additionally, development cycles of battery systems for automotive applications are characterized by long development periods. Hence, the initiatives to advance electrification result in numerous development projects affiliated with significant development expenses. Battery systems can be referred to as mechatronic and electrochemical systems. They require a complex interaction of diverse scientific and engineering disciplines. Fast innovation cycles have effects regarding product requirements and assumptions towards their allocation. Hereby, uncertainties can lead to risks within development projects, especially in terms of time and costs. In current development processes, necessary changes are only dealt with reactively, causing unplanned additional expenses and delays. Thus, there is need for handling potential changes proactively, i.e. managing uncertainties leading to those changes as early as possible. New methods are necessary to identify and handle uncertainties of complex product systems within requirements engineering. An approach towards comprehensive uncertainty management is taken within this publication.
\end{abstract}

Keywords Uncertainty management $\cdot$ Battery systems $\cdot$ Product requirements $\cdot$ Product development $\cdot$ Battery systems engineering

\section{Introduction}

Today's product development projects in the automotive industry are usually characterized by fundamental challenges: volatility, uncertainty, complexity and ambiguity (VUCA) [1]. The centre of the VUCA framework is the situation of complexity, which has direct and indirect influence on all other variables and is therefore responsible for an increasing degree of uncertainty.

Companies are affected by this uncertainty in various ways [2]. A major driver of uncertainty in the mobility sector is disruptive change.

Especially the shift towards electric drive trains opposes major changes. Three main drivers are responsible for the pressure on OEMs regarding development of electric cars.

Andreas Haunreiter

a.haunreiter@pem.rwth-aachen.de

1 Chair of Production Engineering of E-Mobility Components, RWTH Aachen University, Aachen, Germany
First, paradigm shifts in customer requirements towards greater environmental awareness and the increased political efforts to tighten the conditions regarding emissions will facilitate the shift to electric drive train technology. Second, raw material shortages lead to higher fuel prices and in turn to alternative mobility concepts. Third, political efforts consist of two different instruments. On the one hand, existing global $\mathrm{CO}_{2}$ regulations are being revised and tightened. Example regions for tightened emission regulations are the European Union, United States, China and Japan who have set limits on $\mathrm{CO}_{2}$ emissions by 2020 [3]. On the other hand, governments encourage people with incentive packages to buy electrified cars [4].

The mentioned drivers cause model announcements by established and new competitors. This leads to various development projects to bring new electric power train components to the market. In addition to the electric motor and power electronics, battery systems represent the main value-adding component of the of electric vehicles. Battery systems are the most cost-intensive part of new vehicle 
models. Today, the battery accounts for about $40 \%$ of the total vehicle costs [5].

Consequently, the drive train substitution has got unprecedented dimensions, which impact the overall rivalry among competitors in the market. This fact is manifested in model offensives by many manufacturers to secure their market shares at an early stage of this substitution process. The Volkswagen Group alone plans to upgrade 16 production sites around the world for the integration of electric vehicles. Along with this investment, VW intends to launch 27 electric vehicle models across all brands until 2022. Within the company, this approach leads to a realignment of their corporate strategy. Due to market turbulence, there is still a high degree of uncertainty regarding future strategic and structural decisions [6].

After a short overview of the structure of battery systems, this paper deals with the identification of dependencies between product requirements and battery system components. This is followed by a response to the question of which requirements create uncertainties in the development process of battery systems. By identifying uncertainties systematically, viable management approaches are possible to eliminate the degree of uncertainty at an earlier stage.

\section{State of the art}

The following chapter deals with the generic product structure of high voltage battery systems employed in automotive applications. Further, the general product requirements and restrictions that need to be considered in the development of battery systems are outlined. Moreover, a general process structure for product development is presented and the major challenges in requirements engineering and management are addressed.

\subsection{Product structure of battery systems}

The structure and functionality of battery systems can be clearly derived based on five integration levels starting with the cell material up to the final vehicle integration (Fig. 1).

The value chain starts on raw material level, which plays an important role for the properties of a battery cell. Depending on the application, properties such as energy density, service life and aging effects can be adjusted by combining different cell materials [8]. The next stage of integration is the battery cell. Each cell requires two electrodes, a cathode and an anode, a separator as well as electrolyte, which can be liquid, solid or in a hybrid form depending on the type of application and specification [9]. The mentioned components are applied in layers. While the anode usually consists of graphite, eventually combined with a minority of silicon, cathode material vary in different applications. The separator is used to isolate the cathode and anode through a membrane, which is only permeable for small lithium ions. This important part of the cell typically consists of a thin plastic or ceramic layer [10]. Various mechanical designs have been established on the market. These include the round cell, the pouch cell and the prismatic cell. Round cells have standardized sizes $(18650,21700)$. The cell design for prismatic and pouch cells can vary from manufacturer to manufacturer, although the DIN 91252 provides standardized geometric parameters [11].

In the next step, battery cells are integrated into a battery module. The structure of the module results from the selected cell design and represents a mechanical enclosure. In addition, a module usually provides several sensors for monitoring the temperature and condition of all single cells for control and safety reasons [12].

For further integration, a set of modules is integrated into a battery pack. Within the battery pack, the battery modules are connected, and the pack represents a mechanical shell. The thermal system is also integrated in the battery pack. Cells are controlled and monitored by a battery management system (BMS). Sockets let the high (HV) and low voltage (LV) and thermal system connect to the outside [13].

At the final integration level, the battery pack is assembled to the vehicle. The size and position of the installation space are of relevance as these parameters must be considered when designing the battery pack and its components. The required installation space can vary between full electric vehicles and hybrid electric vehicles. Full-electric vehicles typically use the underfloor structure of the car's body between both axles, whereas hybrids use free space under the back seats or the centre tunnel [14-16].

Using a tree diagram (Fig. 2), the battery system, module and cell can be divided into subassemblies and components, which represent the generic product architecture of battery systems. The system groups represent the previously described integration levels. The battery system generally consists of battery modules, the LV-system and HV-system, the temperature control unit, external interfaces and the system housing. This structure provides the basis for all further
Fig. 1 Integration levels of a battery system [7]

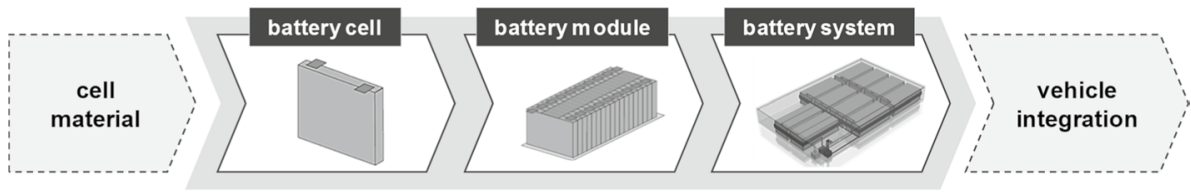


sections in this paper, especially to connect requirements and product features.

\subsection{Product requirements of battery systems}

This chapter derives general requirements for a battery system and assigns these requirements to categories. The main categories refer to technical, economic and legal requirements as well as the technical-related environment. Figure 3 gives an overview of these categories and related sub-categories.

When designing battery systems, diverse topics must be considered, including the determination of the application requirements and possible operating ranges, safety characteristics, selection of suitable electrochemical technologies, design and/or evaluation of the electrochemical cell. In general, an energy storage system can range from a single cell to large systems that combine a big number of cells into a single system. The suitability of a battery system for a certain application can be reduced to the capability to operate that application adequately. Thus, the first step in the development of a battery system is to understand the various demands that a specific application presents and the requirements that result from that. In automotive development, dealing with a high energy capacity within limited assembly space under certain operating conditions over a period of more than 10 years is a challenging task [17].

The identification and prioritization of requirements for a battery system present a major challenge, regardless of the requirement level. A common approach to meet customer requirements concerning specific product functions is the Quality Function Deployment (QFD). In this systematic approach the customer requirements are weighted and matched with the product functions and quality characteristics based on the degree of fulfilment. The application of QFD can improve certain features and product components that are critical to customer satisfaction. This allows the product to be viewed from both, a market perspective and in terms of its technical importance, in order to identify the key requirements concerning customer needs at an early stage [18].

An integrated view of product, production, market and legal requirements must precede research and development to achieve comprehensive transparency about the product's technical und functional requirements. An inadequate lack of focus on the requirements leads to cost-intensive overengineering [19].

\subsection{Battery system development}

Product development processes serve for a structured, methodical approach towards industrialization of a product
[20]. In Fig. 4, the basic phases of a development process are outlined and described with the background of battery systems.

As shown in Fig. 4, product development consist of four phases until series production level is achieved. The phases are pre-program planning, concept development and selection, series development and an industrialization phase.

The pre-program planning as introductory phase contains the mission statement and market research to assess options for product definition. As soon as the product is defined (e.g. key characteristics of the battery system such as energy content and available assembly space) concept development takes over. Here, customer needs and feasibility analyses result in the product requirements (cf. Sect. 2.2). Moreover, key suppliers are screened, and concept development is achieved after proof of general feasibility. These main activities are supported by market research and business plan development (alternatively part of pre-program planning). The phase ends with a battery concept selection and the program approval. The detailed battery engineering activities within series development include design of exterior and interior components. Furthermore, the phase incorporates battery systems packaging, and design of subsystems, components as well as verification testing of the battery system with regard to fulfilment of requirements by system and sub component design. The last phase before entering series production is called industrialization phase. The main purpose is the conversion of an engineered battery system to a manufacturable battery system. The main manufacturing development activities are process engineering, design of facilities and tooling, pilot battery assembly, testing of battery prototypes for verification and validation.

As battery systems are critical in terms of safety, their verification and validation process through prototypes is important. The prototypes contain A-, B-, C- and D-samples which evolve in product maturity towards the final product. The A-prototype focuses on the proof-of-concept. This means the feasibility is examined with a few hand-built prototype battery systems to validate the technical concept. After this, the B-sample as a functional prototype provides the basic performance characteristics. The next prototype stage is the C-sample, which is manufactured in a low-volume. It validates the full design and the most important production processes are already carried out on series production level. Finally, the D-prototype validates that the product is fit for series production. It is a direct transition into series production [21]. 


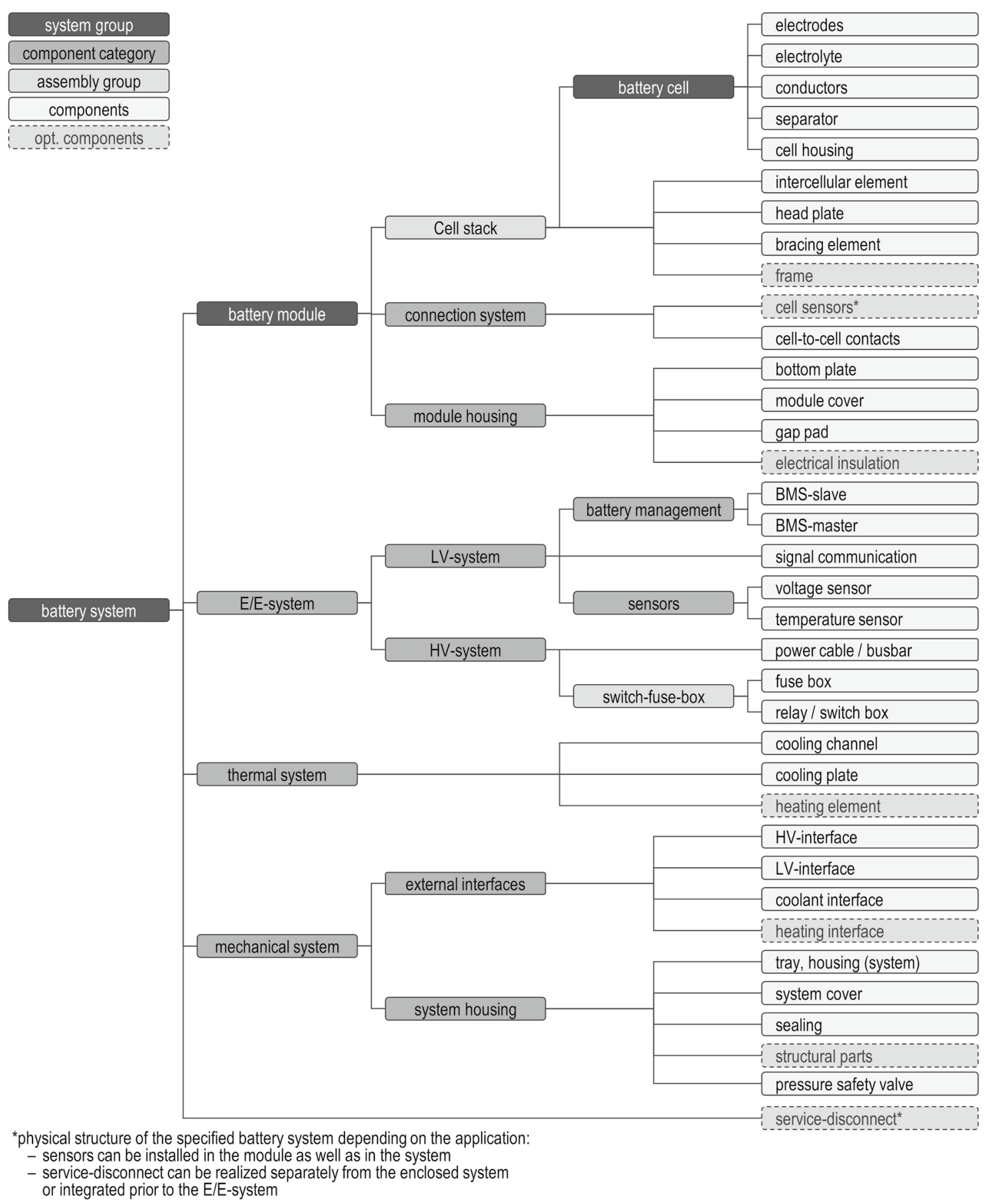

Fig. 2 Exemplary product architecture of a battery system

\subsection{Requirements engineering \& related uncertainties}

The process of requirements engineering contains all activities related to the discovery, negotiation, documentation and maintenance in product development projects. Requirements engineering is a process, which permits eliciting, negotiating and documenting the functionalities and restrictions of the product, i.e. the product requirements. Its objectives are the explicit knowledge of product characteristics which are necessary to completely fulfil the intended function of a battery system. Requirements are documented at a certain level of detail to have an agreement about a set of requirements among the stakeholders. Requirements need to be fulfilled 


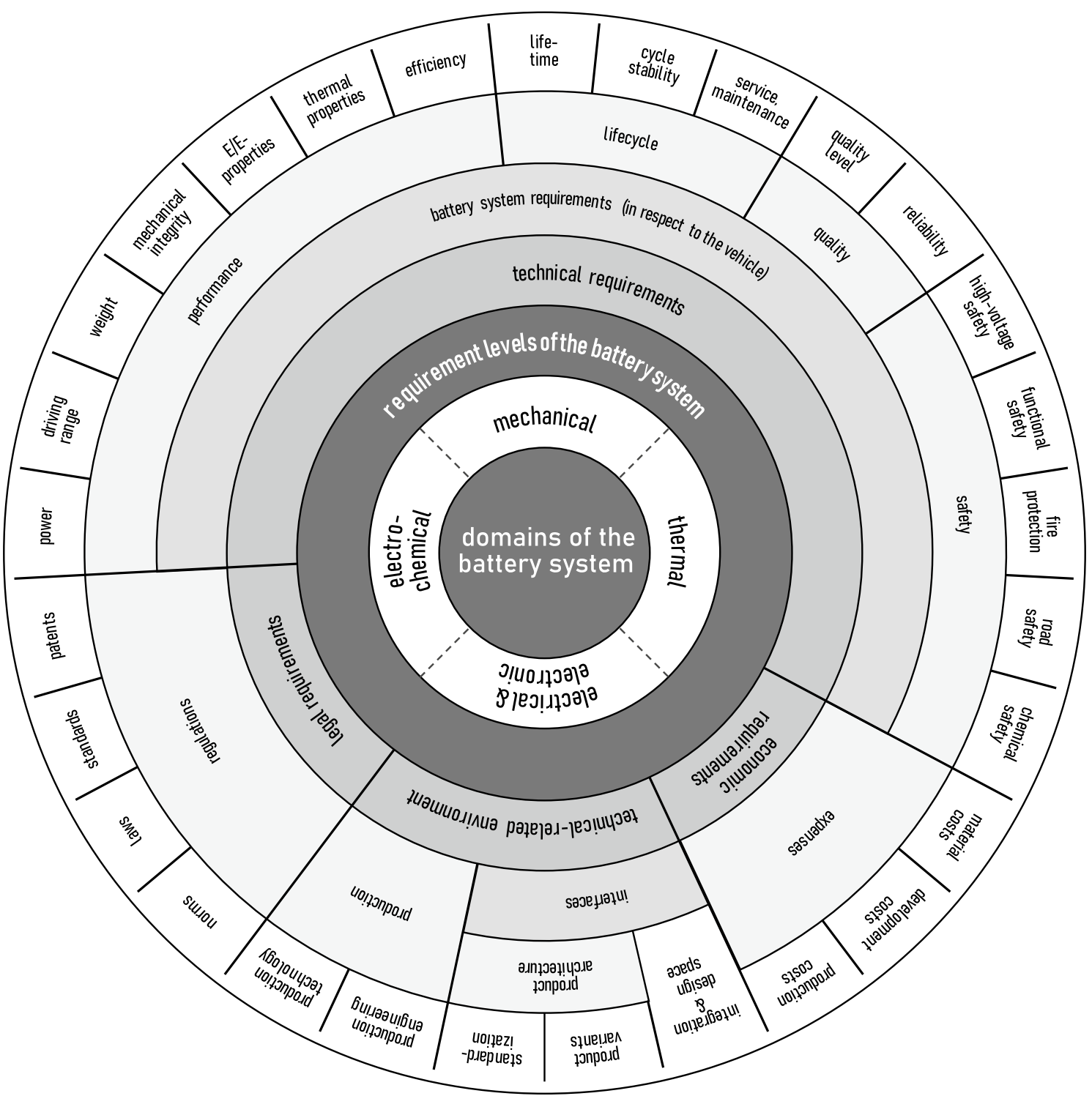

Fig. 3 Exemplary overview of requirements levels and categories

by the final product. Thus, they are a decisive factor for a successful battery development [22]. After the negotiation and agreement on the list of requirements, requirements management takes over. Requirements management is the process which assigns attributes to requirements, prioritizes requirements, manages changes and measures the degree to which requirements are fulfilled. Besides the management of individual requirements, it also manages the respective requirement documentation [23].

The consequences of the change towards automotive electrification set the boundary conditions for automotive companies and cause uncertainty factors. The technological change from combustion engine technology to the electric drive train is the origin of internal and external uncertainties regarding different aspects within requirements engineering.
Generally, the occurrence of uncertainty originates due to lack of information. Hence, the collection of necessary information will reduce uncertainties. This type of uncertainty is called epistemic uncertainty. However, aleatoric uncertainties exist as well, which occur on a basis of coincidental variation and therefore cannot be reduced [24]. The approach presented in this paper focusses on the identification of uncertainties in battery systems development regarding epistemic uncertainties.

\subsection{Modelling of complex product systems}

During product development, a systematic approach is crucial for modelling the structures and analysing potential subassemblies of the product in order to address its 


\section{Phases Battery Development Process}

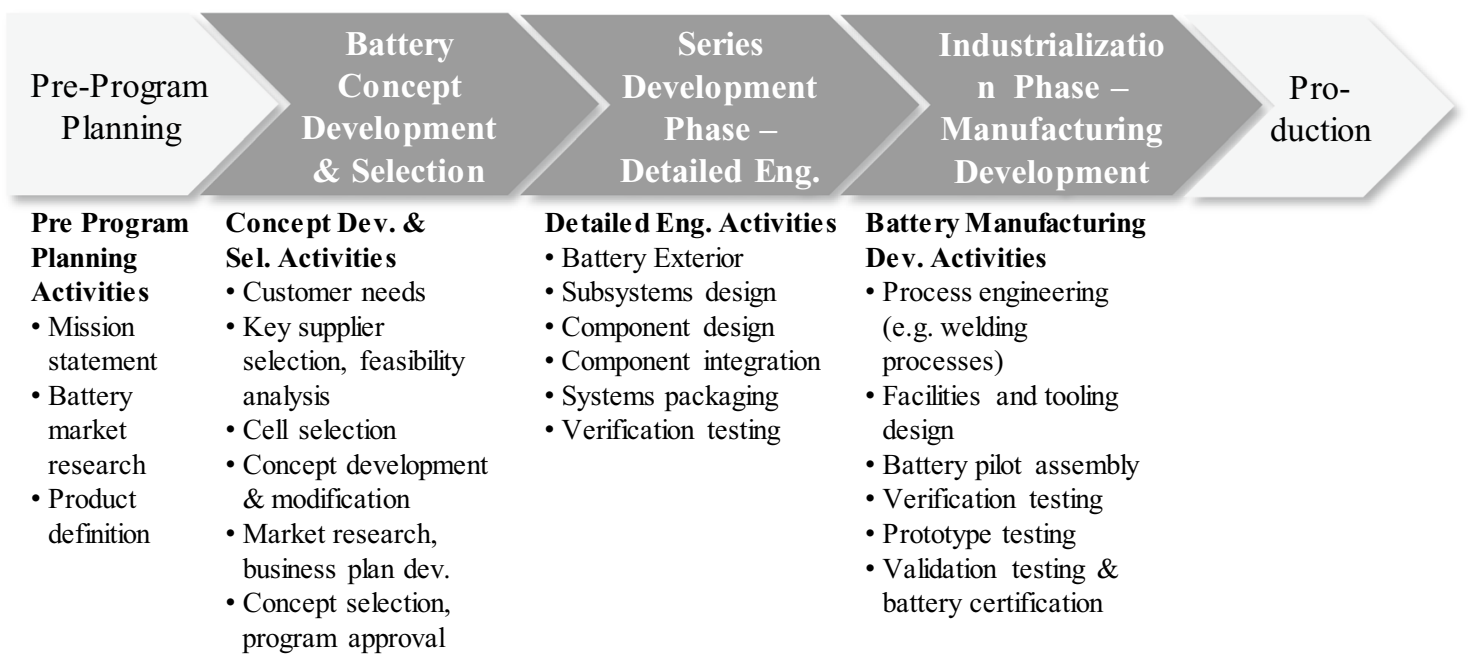

Fig. 4 Generic product development process phases [20]

complexity. Typically, this is accomplished by structuring the large amounts of information in graphs using methods of engineering complexity management. These graphs can be transformed into matrices by formalizing the elements of the system as nodes and the relationships between the elements as edges. This allows the structuring and clustering of a problem with a high complexity, e.g. when developing a product system with a large amount of information and interdependencies. The most common types of system representation matrices are the Design Structure Matrix and the Domain Mapping Matrix.

The Design Structure Matrix (DSM) illustrates the dependencies between two elements of the same class (component, process, function, etc.) and enables the analysis of the structure of product systems by mapping elements of the system and their relationship. This method was then extended by the Domain Mapping Matrix (DMM). In contrast to a DSM, a DMM does not only contain one class of information but focuses the relationships between two classes (e.g. domain of a component) [25, 26].

In Fig. 5 shows an example of a product systems and its structural representation through the coherence of both DSM and DMM. The DSM/DMM methods support understanding the dependencies and interactions within a product system and the exchange of information across domains. Even though, the DSM/DMM framework lacks the information about multiple and time-dependent relationships and dependencies between single node pairs such as requirements and their importance during product development $[25,26]$.

\section{Methodology}

As shown in Sect. 2, DSM and DMM as well as QFD provide major tools in product development regarding product architecture and requirements. In concept development and initial product planning, the identification and analysis of general product and system requirements takes place, followed by the derivation of the general functional and product architecture of the selected solution.

However, the methods presented in Sect. 2 do not fully grasp the relation between technical product requirements and product architecture. The methods in Sect. 2 focus on the relation between product elements and the allocation to product domains. They might facilitate the preparatory steps towards a full understanding of these relations. In order to already identify uncertainties in these early phases of product development, a comprehensive methodology for uncertainty identification is required.

Therefore, the objective of this paper is to present an approach towards uncertainty identification with a complete analysis of interdependencies between functional or nonfunctional product requirements and the functions or specifications of the product architecture as part of the approach. This is an important step to identify potential uncertainties thereafter.

The presented approach consists of two main steps: The first step is to define and document the product architecture model as well as carrying out the preparation of the requirements model. The first step is finalized by combining the product architecture and requirements model to explicitly. This is followed by the second step and the actual 

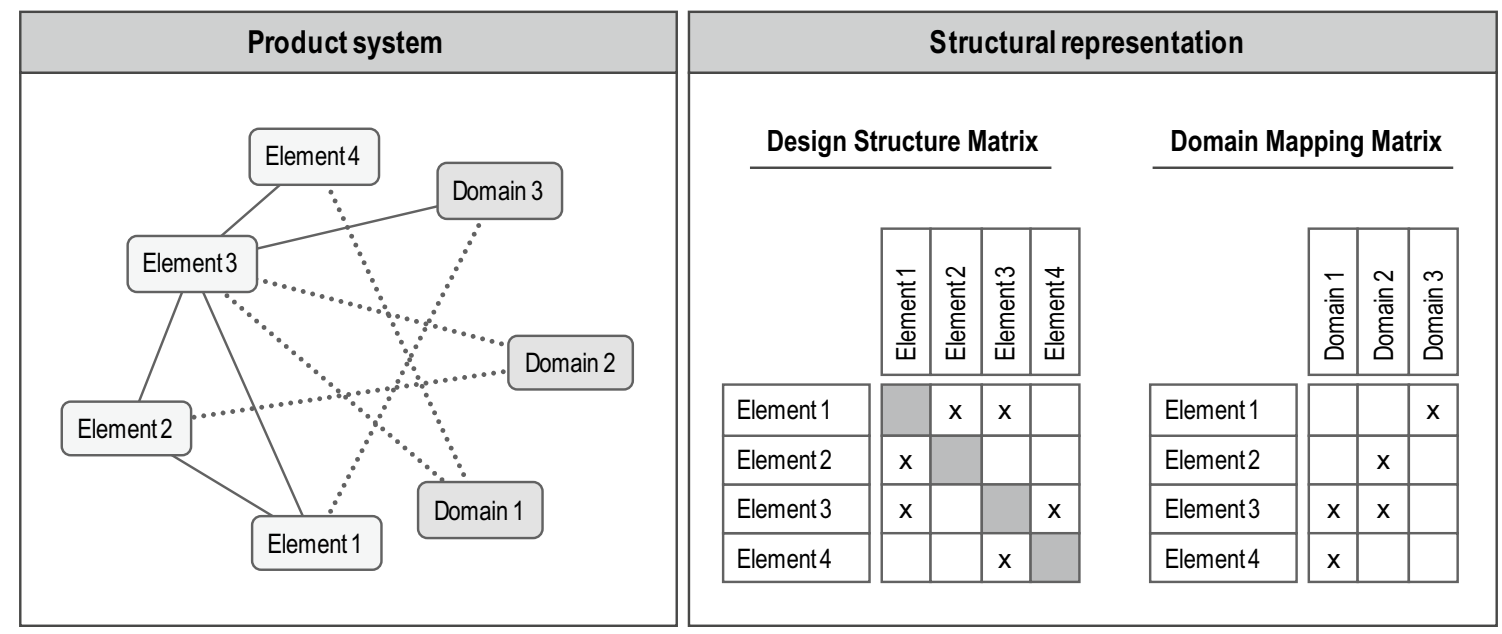

— Dependencies of elements $\cdots .$. Relation to domains

Fig. 5 Structural representation of a product system through DSM and DMM [25]

uncertainty identification regarding product requirements of a battery system.

\subsection{Modelling of product architecture and requirements of battery systems}

The following sections have their focus on modelling a generic product architecture for battery systems, followed by modelling the associated product requirements and their specifications for battery system design. The last step is the final aggregation of both the product architecture and the requirements model.

\subsubsection{Modelling of product architecture}

In general, battery systems for electric vehicles have a physical product structure, which is valid for most battery systems and only deviates in minor aspects. Using a tree diagram in Sect. 2 (Fig. 2), the battery system and module and cells, respectively, can be divided into subassemblies and components. This structure provides the basis to connect requirements with product features.

Additionally, the elements, i.e. product components, can be allocated to the domains that make up the battery system. As the domains in Fig. 6 show, the battery system is a mechatronic system, which contains battery cells as an electrochemical subsystem. Hence, one can relate to the term mechatrochemical system with mechanical, thermal, electrical/electronic and electrochemical domains, when referring to a battery system.

In Fig. 6, a generic overview of battery system components including qualitative classification to their domains is shown. It is shown that cell components mainly refer to the electrochemical domain. Most parts belong, completely or partially, to the electrical/electronic domain.

The documentation of the product architecture and allocation of product elements to their domains supports in the following activities towards uncertainty identification. The categorization in specific domains facilitates an understanding of intended specifications of single product elements. The allocation illustrates the connection to functional domains, as there is no documentation of product specifications in early stages of product development yet.

\subsubsection{Modelling of product requirements}

After the allocation of product elements to functional domains, this section compiles general challenges on the modelling of product requirements resulting in battery system specifications. Requirements engineering and the modelling of product requirements is an important aspect in product development. They contribute to the objectives the needed quality of development work, e.g. requirements identification and documentation, as well as successful product development overall. Particularly for product systems with a distinctive structure, such as a battery system, the inherent variety of requirements and restrictions of the individual components must be considered as a driver for a high number of interdependencies. This fact does not only cause a high level of complexity but is also a potential source for uncertainty.

In Table 1 an exemplary overview of major requirements of battery systems and their respective classification within different requirement categories is shown.

Starting with the collection of customer requirements, requirements engineering is an iterative process of collecting, reviewing and specifying requirements. Here, it 


\begin{tabular}{|c|}
\hline electrode \\
\hline electroly te \\
\hline conductor \\
\hline separator \\
\hline cell housing \\
\hline frame \\
\hline head plate \\
\hline bracing elements \\
\hline celllsensors \\
\hline cell-to-cell contacts \\
\hline intermediate element \\
\hline bottom plate (module) \\
\hline module cover \\
\hline gap pad \\
\hline electrical insulation \\
\hline BMS-slave \\
\hline BMS-master \\
\hline signal communication \\
\hline voltage sensors \\
\hline temperature sensors \\
\hline cooling channels \\
\hline cooling plate \\
\hline heating element \\
\hline load pow er cable / busbar \\
\hline fuse box \\
\hline relay / switch box \\
\hline HV-interface \\
\hline LV-interface \\
\hline coolantinterface \\
\hline heating interface \\
\hline sy stem housing \\
\hline sy stem cover \\
\hline sealing \\
\hline structural parts \\
\hline service disconnect \\
\hline pressure safety valve \\
\hline
\end{tabular}

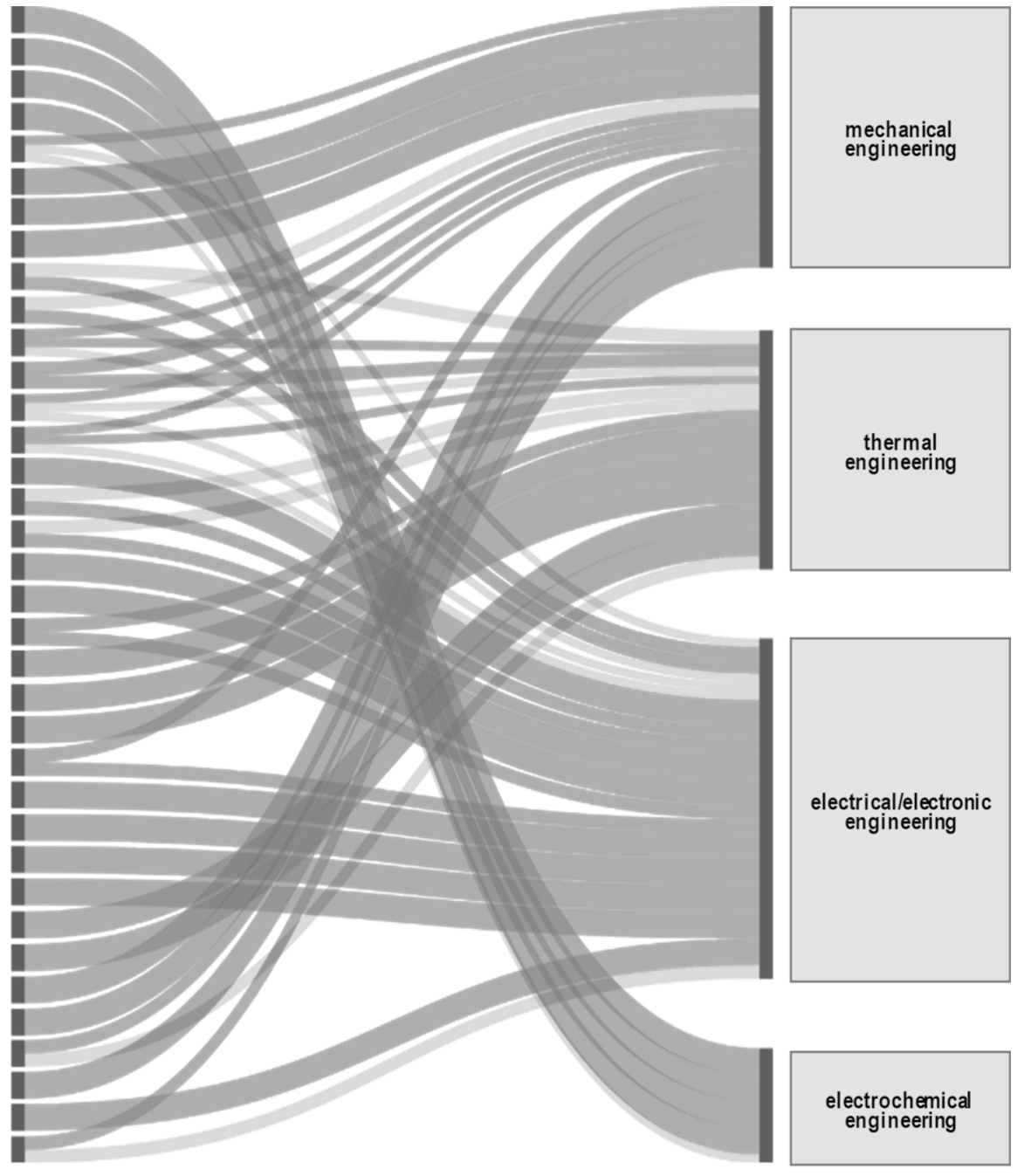

element of the respective design engineering

influence on the respectiv e design engineering

Fig. 6 Allocation of battery system components to engineering domain

is necessary to translate the initial requirements into specific requirement elements and properties. The modelling of product requirements must be mutually exclusive and collectively exhaustive to ensure representing all functional and non-functional requirements fully and should follow a distinctive terminology. Requirements should have a strong semantic consistency as terminologies can be interpreted and applied on various levels and through different perspectives. The variation in interpretation from different perspectives should be kept at a minimum. Therefore, the requirements are continuously specified and iterated during product development.

Ultimately, the requirements model contains all necessary aspects the battery system needs to fulfil. These aspects are documented in a specific and consistent manner. The requirements in Table 1 are taken from literature examples. They still need some iteration to be specified in battery system development but are exact enough to use them in the further parts of the methodology in this paper.

\subsubsection{Product architecture and requirements model matrix}

With an explicit product architecture as well as iterated and documented product requirements, the important step of synthesis of both follows. The synthesis can be executed in an aggregating product architecture $\&$ requirements model (PA\&RM) matrix. As outlined in Fig. 7, the y-axis represents the product architecture and the $\mathrm{x}$-axis contains product requirements and specifications from the requirements 
Table 1 Exemplary requirements in battery system development

\begin{tabular}{|c|c|c|c|c|c|c|c|}
\hline & \multirow[t]{2}{*}{ Requirement } & \multicolumn{2}{|c|}{ Classification in requirement categories } & \multicolumn{3}{|c|}{ System level } & \multirow[t]{2}{*}{ References } \\
\hline & & Category & Requirement level & Cell & Module & System & \\
\hline 1 & Design space & Design space & Integration and design space & $\mathrm{x}$ & $\mathrm{x}$ & $\mathrm{x}$ & {$[16,27,28]$} \\
\hline 2 & Integration of sub-components & Integration & Integration and design space & $(\mathrm{x})$ & $\mathrm{x}$ & $\mathrm{x}$ & {$[19,29,30]$} \\
\hline 3 & Expenses & Expenses & Expenses & $(\mathrm{x})$ & $(\mathrm{x})$ & $\mathrm{x}$ & {$[3,16,27,30,31,35]$} \\
\hline 4 & Cost-effective design & Development expenses & Expenses & (x) & (x) & $\mathrm{x}$ & [19] \\
\hline 5 & Lifetime & Lifetime & Lifetime & $\mathrm{x}$ & & $\mathrm{x}$ & {$[16,27,28,31]$} \\
\hline 6 & Operating limits & Performance & Performance & $(\mathrm{x})$ & & $\mathrm{x}$ & {$[16,32]$} \\
\hline 7 & Charging time & E/E-properties & Performance & $(\mathrm{x})$ & & $\mathrm{x}$ & {$[3]$} \\
\hline 8 & Total weight & Total weight & Performance & $(\mathrm{x})$ & & $\mathrm{x}$ & {$[19,28]$} \\
\hline 9 & Power & Power & Performance & $(\mathrm{x})$ & & $\mathrm{x}$ & {$[27-29,31]$} \\
\hline 10 & Deformation resistance & Mechanical integrity & Performance & & $\mathrm{x}$ & $\mathrm{x}$ & {$[19,30,33]$} \\
\hline 11 & Mechanical resilience & Mechanical integrity & Performance & & $\mathrm{x}$ & $\mathrm{x}$ & {$[19,29]$} \\
\hline 12 & Energy density & Driving range & Performance & $\mathrm{x}$ & & $(\mathrm{x})$ & {$[27,28,31,34,35]$} \\
\hline 13 & Energy capacity & Driving range & Performance & & $(\mathrm{x})$ & $\mathrm{x}$ & {$[16,27,28]$} \\
\hline 14 & Driving range & Driving range & Performance & & & $\mathrm{x}$ & {$[3,27,28,31]$} \\
\hline 15 & Efficiency & Efficiency & Performance & $\mathrm{x}$ & & (x) & {$[31]$} \\
\hline 16 & Product architecture & Product architecture & Performance & & $\mathrm{x}$ & $\mathrm{x}$ & {$[16,19]$} \\
\hline 17 & $\begin{array}{l}\text { Interchangeability of sub-compo- } \\
\text { nents }\end{array}$ & Standardization & Product architecture & $(\mathrm{x})$ & $\mathrm{x}$ & $\mathrm{x}$ & [19] \\
\hline 18 & Production quality & Quality level & Product architecture & $\mathrm{x}$ & $\mathrm{x}$ & $\mathrm{x}$ & {$[28,32]$} \\
\hline 19 & Reliability & Reliability & Quality & $\mathrm{x}$ & $\mathrm{x}$ & $\mathrm{x}$ & {$[27,28,35]$} \\
\hline 20 & Recyclability & Laws & Quality & $\mathrm{x}$ & & $\mathrm{x}$ & [19] \\
\hline 21 & Second-life usage & Laws & Regulations & & $\mathrm{x}$ & $\mathrm{x}$ & [19] \\
\hline 22 & Functional safety & Functional safety & Safety & $(\mathrm{x})$ & $(\mathrm{x})$ & $\mathrm{x}$ & {$[28-30,33,36]$} \\
\hline 23 & Electrical insulation of components & High-voltage safety & Safety & $(\mathrm{x})$ & $\mathrm{x}$ & $\mathrm{x}$ & {$[19,30,33]$} \\
\hline 24 & High-voltage safety & High-voltage safety & Safety & & $\mathrm{x}$ & $\mathrm{x}$ & {$[19,36]$} \\
\hline 25 & Safety & Safety & Safety & $(\mathrm{x})$ & $(\mathrm{x})$ & $\mathrm{x}$ & {$[3,16,27,28,31,35]$} \\
\hline 26 & Crash performance & Road safety & Safety & $(\mathrm{x})$ & $(\mathrm{x})$ & $\mathrm{x}$ & {$[19,28,30]$} \\
\hline 27 & Hazard prevention for traffic use & Road safety & Safety & $(\mathrm{x})$ & (x) & $\mathrm{x}$ & {$[28,33]$} \\
\hline 28 & Impact resistance & Road safety & Safety & & & $\mathrm{x}$ & [19] \\
\hline 29 & Cycle stability & Cycle stability & Cycle stability & $\mathrm{x}$ & & & {$[27,32,34]$} \\
\hline 30 & Cycle lifetime & Cycle stability & Cycle stability & $\mathrm{x}$ & & & {$[27,34]$} \\
\hline
\end{tabular}

$x$ requirement highly applicable, $(x)$ requirement indirectly applicable

list. The synthesis process to aggregate the elements into a product architecture and requirements model is suggested to use the following scheme for the evaluation of the relationship between requirement and product architecture element.

- 0 points: no significant relationship

- 1 point: low level relationship

- 3 points: medium level relationship

- 9 points: high level relationship

The example in Fig. 7 contains an excerpt from the product architecture in Fig. 2 (cf. Sect. 2) and the product requirements from Fig. 3 (cf. Sect. 2). Each element intersection is weighted one by one. In consequence, the matrix provides an overview of relationships between product requirements and product architecture.

Over time, the relationships between requirements and product architecture may evolve, what makes a regular update for the matrix necessary. An iteration to update the matrix is at least required, if the product architecture changes as well as if a requirement is added or disposed. 
Fig. 7 Product architecture and requirements model (PA\&RM) matrix for the development of a battery pack

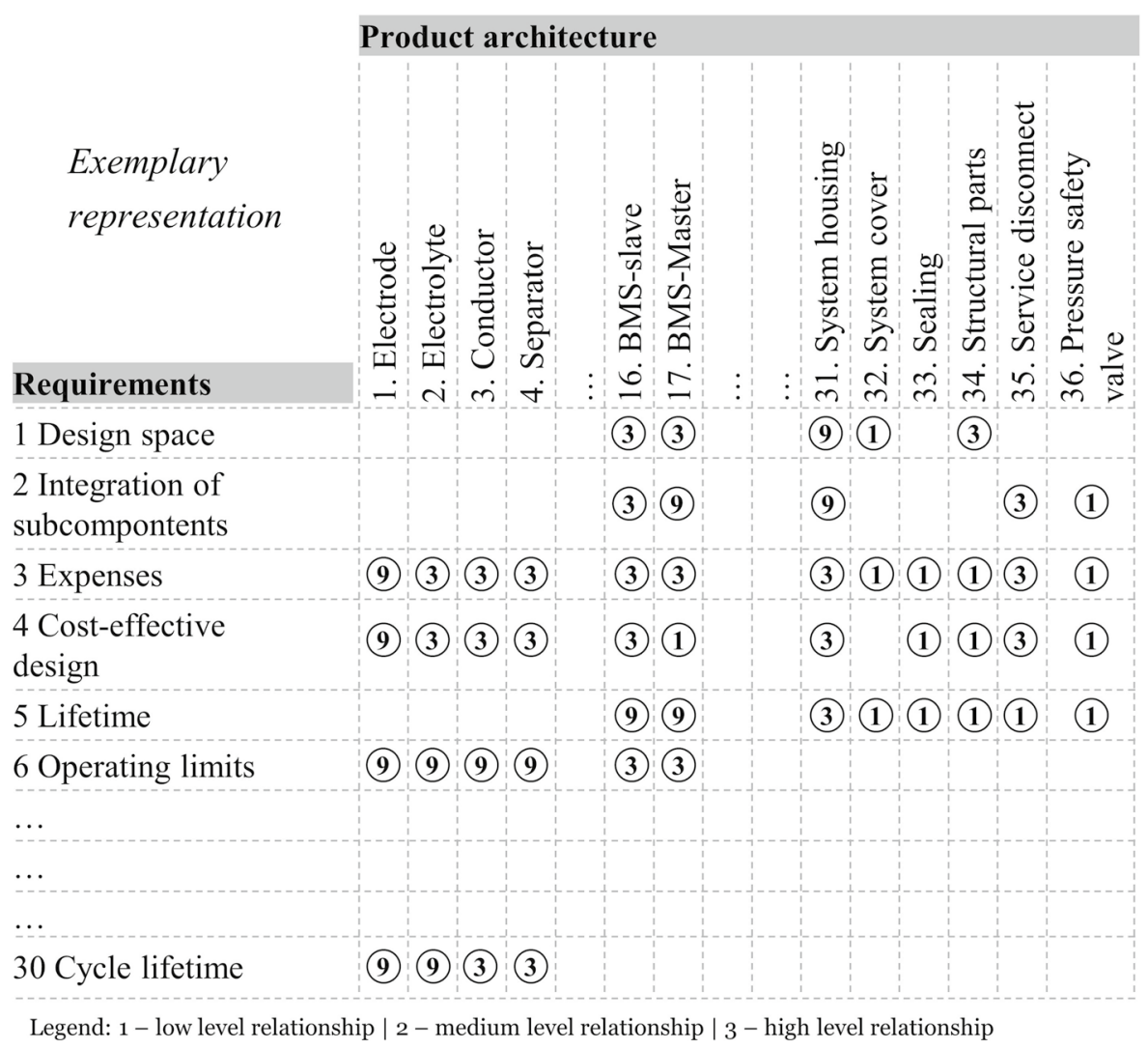

\subsection{Approach in identification of uncertainties}

In the previous sub chapter, the requirements for battery systems development and the product architecture are modeled generically and synthesized by aggregating them in the product architecture and requirements model matrix. This is preparatory groundwork for identifying uncertainties.

In general, relevant uncertainties for the development of battery systems can occur in several aspects. On the one hand, customer needs should be fulfilled completely. This is accomplished by the adherence of the final industrialized battery system to its product requirements. If requirements are not described completely or leave room for interpretation, i.e. there is unknown or unspecified content, uncertainties can occur in consequence. On the other hand, information gaps may appear regarding components of the product architecture and their specifications. For example, system housing and the requirement to integrate subcomponents, i.e. integration must be accomplished, have a high relation level (see Fig. 7). This connection can be investigated for uncertainty. If the dimensions of the battery housing are not defined, there is uncertainty concerning the ability to integrate all components.

Overall, the identification of uncertainties is done systematically by going through the rows and columns of the product architecture and requirements model matrix searching for uncertainties at every entry in the matrix.

Once these gaps are found, there is a need to analyze the impact of the uncertainty on other elements of the product architecture and requirements, respectively.

\section{Discussion}

The introduced approach from Sect. 3 allows a systematic identification of uncertainties within the development of battery systems. The preparation for uncertainty identification contains three steps, which are necessary to provide the basis for uncertainty identification. First, the product structure of the battery system is modelled. This is followed by the requirements model. The third step is the aggregation in the PA\&RM matrix, wherein battery system components are connected to requirements. After the preparatory steps, the uncertainties are identified systematically by analysis of all interconnections within the PA\&RM matrix. The identification of uncertainties can be accomplished by exploring the PA\&RM matrix for information gaps. Here, the analysis could be prioritized according to the intensity of the relation $(1,3$ or 9 points, cf. Sect. 3.1.3). However, the identification is only a first step towards a methodology of uncertainty management. 
The battery system is very complex as mechatrochemical system (cf. Sect. 3.1.1) and uncertainties are a significant aspect. The primary objective of introducing uncertainty management is to have a systematic approach in handling uncertainties and, in consequence, risks resulting from the impact uncertainties can have on battery development. In particular, negative impact causes deficiencies in terms of time and cost within product development. In consequence, the methodical approach presented in this paper needs to be extended with an analysis and evaluation of uncertainties. This is necessary to deduce appropriate and economic measures to avoid negative impact by uncertainties. Moreover, uncertainty management must be aligned with the activities within requirements engineering and management and the development process in general. Uncertainty management has the potential to be a significant part of requirements management and integrating aspects from requirements engineering as well as requirements change and risk management. For example, it analyses the requirements list, allocated to requirements engineering, identifies uncertainties, which impose risks (risk management) and defines measures to handle uncertainties (requirements management).

After analysing and evaluating uncertainties the management approach needs to be economically viable, i.e. the benefit must outweigh the cost. A cost-benefit-analysis is necessary to get to know the economic impact of an uncertainty, its induced risk to product development and potential measures to handle that uncertainty/risk. This should be focused in further research.

\section{Conclusion}

As business processes, such as battery system development, gain more uncertainty in general nowadays, there must be ways established to minimize risks, which are a consequence of uncertainty. For this, uncertainty management can deliver an important aspect in reducing risks in battery systems development. This research paper presents an approach towards uncertainty management in battery systems development by presenting a methodology for the systematic identification of occurring uncertainties regarding product requirements and product architecture. After presenting basic principles in battery systems technology, requirements engineering and development processes, the current challenges concerning uncertainties in battery systems development are examined in Sect. 2. In Sect. 3, the methodology is presented-divided into two parts. The first part deals with the product architecture and requirements model, aggregated in the PA\&RM matrix. The second part describes the approach to identify uncertainties using the PA\&RM matrix. The evaluation of this approach to identify uncertainties and its role within an overall framework for uncertainty management is clarified in Sect. 4.

In further research, the approach towards uncertainty management needs to be detailed and refined. Moreover, it is necessary for the methodical approach, worked out in academic manner, to be validated in practice. This is to prove that the means of uncertainty management are effective in battery system development projects.

Funding Open access funding provided by Projekt DEAL.

Open Access This article is licensed under a Creative Commons Attribution 4.0 International License, which permits use, sharing, adaptation, distribution and reproduction in any medium or format, as long as you give appropriate credit to the original author(s) and the source, provide a link to the Creative Commons licence, and indicate if changes were made. The images or other third party material in this article are included in the article's Creative Commons licence, unless indicated otherwise in a credit line to the material. If material is not included in the article's Creative Commons licence and your intended use is not permitted by statutory regulation or exceeds the permitted use, you will need to obtain permission directly from the copyright holder. To view a copy of this licence, visit http://creativecommons.org/licenses/by/4.0/.

\section{References}

1. Bennett, N., Lemoine, G.J.: What a difference a word makes: understanding threats to performance in a VUCA world. Bus. Horiz. 57(3), 311-317 (2014)

2. Mack, O., Khare, A.: Perspectives on a VUCA world. In: Mack, O., Khare, A., Kramer, A., Burgartz, T. (eds.) Managing in a VUCA, World, 2016, pp. 3-19

3. Schott, B., Püttner, A., Müller, M.: The market for battery electric vehicles. In: Scrosati, B., Garche, J., Tillmetz, W. (eds.) Advances in Battery Technologies for Electric Vehicles, vol. 80, pp. 35-54. Woodhead Publishing, Sawston (2015)

4. Scheremet, D.W.: Bundesanzeiger, Richtlinie zur Förderung des Absatzes von elektrisch betriebenen Fahrzeugen (Umweltbonus), BAnz_AT_02.03.2018_B1 (2018). https://www.bunde sanzeiger.de/

5. Soulopoulos, N.: When will electric vehicles be cheaper than conventional vehicles. Bloomberg New Energy Finance 12, 1-13 (2017)

6. Al-Alawi, B.M., Bradley, T.H.: Review of hybrid, plug-in hybrid, and electric vehicle market modeling studies. Renew. Sustain. Energy Rev. 21, 190-203 (2013)

7. Kampker, A.: Elektromobilproduktion. Springer, Berlin (2018)

8. Rahn, C.D., Wang, C.Y.: Battery Systems Engineering. Wiley, Hoboken (2013)

9. Luo, X., Wang, J., Dooner, M., Clarke, J.: Overview of current development in electrical energy storage technologies and the application potential in power system operation. Elsevier Appl. Energy 137, 511-536 (2015)

10. Warner, J.: The Handbook of Lithium-Ion Battery Pack Design. Chemistry, Components, Types and Terminology, Chemistry, Components, Types and Terminology. Elsevier, Amsterdam (2015)

11. Brown, S., Pyke, D., Steenhof, P.: Electric vehicles: the role and importance of standards in an emerging market. Energy Policy 38(7), 3797-3806 (2010)

12. Lu, L., Han, X., Li, J., Hua, J., Ouyang, M.: A review on the key issues for lithium-ion battery management in electric vehicles. J. Power Sources 226, 272-288 (2013) 
13. Dincer, I., Hamut, H.S., Javani, N.: Thermal Management of Electric Vehicle Battery Systems. Wiley, Hoboken (2017)

14. Fuchs, J., Huber, R., Lienkamp, M., Riemenschneider, T.: Impact of electrification on the vehicle concept: potential of determining components. In: Lienkamp, M. (ed.) Conference on Future Automotive, Technology, pp. 119-146. Springer, Berlin (2013)

15. Arora, S., Kapoor, A., Shen, W.: Application of robust design methodology to battery packs for electric vehicles: identification of critical technical requirements for modular architecture. Batteries 4, 30 (2018). https://doi.org/10.3390/batteries4030030

16. Staeves, J.: Karosseriebau für die Elektromobilität, Darmstadt (2018)

17. Santhanagopalan, S., Smith, K., Neubauer, J., Kim, G.H., Keyser, M., Pesaran, A.: Design and Analysis of Large Lithium-Ion Battery Systems. Artech House, London (2014)

18. Francis, F.: Engineering approach with quality function deployment for an ABET accredited program: a case study. Am. J. Mech. Eng. 4(2), 65-70 (2016)

19. Schuh, G.: Innovationsmanagement, Handbuch Produktion und Management, vol. 3. Springer, Berlin (2012)

20. Bhise, V.D.: Automotive Product Development: A Systems Engineering Implementation. CRC Press, Boca Raton (2017)

21. Total Battery Consulting (Battery Packs of Modern xEVs Report) (2016)

22. Fernandes, J.M., Machado, R.J.: Requirements in Engineering Projects. Springer, Berlin (2016)

23. Pohl, K., Rupp, C.: Basiswissen Requirements Engineering. Dpunkt Verlag, Heidelberg (2015)

24. Engelhardt, R., Kloberdanz, H., Mathias, J., Birkhofer, H.: An approach of a model to describe uncertainty in technical systems. In: International Design Conference, pp. 213-222 (2010)

25. Schmidt et al. (Analyzing industrial clusters using measures of structural complexity management. In: Browning et al.: Modeling and managing complex systems) (2015)

26. Bartolomei et al. (Analysis and Applications of Design Structure Matrix, Domain Mapping Matrix, and Engineering System Matrix Frameworks Part 1: Modeling Frameworks) (2007)

27. Linse, C., Kuhn, R.: Design of high-voltage battery packs for electric vehicles. In: Scrosati, B., Garche, J., Tillmetz, W. (eds.) Advances in Battery Technologies for Electric Vehicles, vol. 80, pp. 245-263. Woodhead Publishing, Sawston (2015)
28. Herrmann, F., Rothfuss, F.: Introduction to hybrid electric vehicles, battery electric vehicles, and off- road electric vehicles. In: Scrosati, B., Garche, J., Tillmetz, W. (eds.) Advances in Battery Technologies for Electric Vehicles, vol. 80, pp. 3-16. Woodhead Publishing, Sawston (2015)

29. Kim, H., Oh, S.M., Scrosati, B., Sun, Y.K.: High-performance electrode materials for lithium-ion batteries for electric vehicles. In: Scrosati, B., Garche, J., Tillmetz, W. (eds.) Advances in Battery Technologies for Electric Vehicles, vol. 80, pp. 191-241. Woodhead Publishing, Sawston (2015)

30. Vogt, M.: Functional safety in vehicles. In: Korthauer, R. (ed.) Lithium-Ion-Batteries: Basics and Applications, pp. 285-299. Springer, Berlin (2018)

31. Perner, A., Vetter, J.: Lithium-ion batteries for hybrid electric vehicles and battery electric vehicles. In: Scrosati, B., Garche, J., Tillmetz, W. (eds.) Advances in Battery Technologies for Electric Vehicles, vol. 80, pp. 173-190. Woodhead Publishing, Sawston (2015)

32. Kampker, A., Heimes, H.H., Lienemann, C., Sarovic, N., Ganser, J.P.: Flexible Product Architecture and Production Process of Lithium-Ion Battery Modules (2018)

33. Martin, H., Leitner, A., Winkler, B.: Holistic Safety Considerations for Automotive Battery Systems, Automotive Battery Technology, Applied Sciences and Technology, pp. 1-17. Springer, Berlin (2014)

34. Lamp, P.: Requirements for batteries used in electric mobility applications. In: Korthauer, R. (ed.) Lithium-Ion-Batteries: Basics and Applications, pp. 371-391. Springer, Berlin (2018)

35. Pistoia, G.: Lithium-Ion Batteries Advances and Applications. Elsevier, Amsterdam (2014)

36. Hauser, A., Kuhn, R.: High-voltage battery management systems (BMS) for electric vehicles. In: Scrosati, B., Garche, J., Tillmetz, W. (eds.) Advances in Battery Technologies for Electric Vehicles, vol. 80, pp. 265-282. Woodhead Publishing, Sawston (2015)

Publisher's Note Springer Nature remains neutral with regard to jurisdictional claims in published maps and institutional affiliations. 